\author{
BENIAMIN KOSTRUBIEC \\ Uniwersytet Śląski, Sosnowiec
}

\title{
Delokalizacja przedsiębiorstw - przejaw światowej samoregulacji
}

Kapitalistyczny system gospodarczy opiera się na umiędzynarodowieniu ekonomii. Polega na poszukiwaniu zewnętrznych chłonnych rynków zbytu i możliwości produkcji jak najmniejszymi kosztami. Dawniej taka dążność była bodźcem do organizowania podbojów kolonialnych. Obecnie światowy pokojowy porządek ekonomiczny i logika finansowa jest odmienna, stanowi jednak powód zaburzeń procesów produkcyjnych.

Według definicji Funduszu Monetarnego, globalizacja to „wrastająca gospodarcza współzależność krajów świata, spowodowana wzrostem woluminu i rodzajów transgranicznych transakcji dóbr i usług, międzynarodowych przepływów kapitałów, z równoczesną przyspieszoną i uogólnioną dyfuzją technologii”. Świat wszedł w erę gospodarki globalnej. Globalizacja wzbudza kontrowersje, w równym stopniu dzieli, jak i jednoczy. Przedsiębiorstwa skłaniają się do delokalizacji produkcji do krajów o znaczącym wzroście ekonomicznym i względnie słabych kosztach produkcji. Dokonują tego po uprzednim rozpoznaniu chłonności rynku, kondycji społeczno-ekonomicznej istniejącej w krajach goszczących. Globalizacji towarzyszy wynarodowienie końcowego produktu, uniemożliwiające jego „narodową" identyfikację.

Proces delokalizacji rozwinął się w latach 90., zwłaszcza po zapaści systemu komunistycznego. Delokalizacja, to transfer aktywności ekonomicznych z kraju na terytorium własne lub innego państwa. Rozwija się w czasie i przestrzeni i tendencja ta wzmacnia się. Polega ona na przeniesieniu całości lub filii jednostki produkcyjnej do regionu oferującego mierzalne korzyści. Zatem, jest to rozdzielenie miejsc produkcji lub przetwarzania dóbr od miejsc ich konsumpcji. Jako mechanizm integrujący, równocześnie rozregulowujący systemy gospodarcze krajów poddanych międzynarodowej konkurencji, reorientuje strumienie handlowe. Lokalizacja firm, postrzegana może być jako alternatywa dla ucieczki „mózgów”. Ta reorganizacja geograficzna różnic działalności jest różnie oceniana przez zainteresowanych, tak konsumentów jak i producentów.

Ponadnarodowe postrzeganie korporacji polega na zamknięciu lub częściowym wygaszaniu narodowej produkcji, by w następstwie otworzyć produkcję i kontrolować zagraniczne jednostki. Dopuszcza się reimport dóbr wyprodukowanych w regionie goszczącym dla obsłużenia i pobudzenia własnego rynku. Delokalizacja zmienia zagospodarowanie przestrzenne i zuboża infrastrukturę opuszczonego obszaru. Powoduje utratę finansów publicznych, a zatem utratę lokalnych stanowisk pracy. Miejscowe władze domagają się ochrony zwolnionych załóg, odpowiednich reglamentacji, utworzenia „paktu socjalnego” oraz harmonizacji obciążeń fiskalnych. Nawet niedoskonała globalizacja jest niewątpliwym 
postępem w obszarze obejmującym podobszary delokalizacji. Zasadniczym celem jest szybka likwidacja różnic w poziomie życia mieszkańców. Im większy jest obszar działań, im dłuższy czas i skala, tym ryzyko słabsze, a bilans ewentualnych strat jest korzystniejszy. Zadaniem rządów jest czuwanie nad prawidłowym przebiegiem tych procesów by zażegnać ewentualne konflikty, jakie mogą zrodzić. Znana reguła przestrzenna powiada, że im większy obszar działań, tym słabsze dysproporcje.

W okresie dekoniunktury, pomimo dobrej kondycji firmy, przedsiębiorca poszukuje stref z tanią i wyspecjalizowaną siłą roboczą. Zadanie ułatwia fakt, że przedsiębiorstwa stają się luźnymi strukturami, często przestrzennie rozproszonymi. Przyjmuje tam zakłady przemysłowe w stanie upadłości lub rywalizujące z jego produkcją, może im narzucić swoją dominującą pozycję. Zdarza się, że na skutek niekorzystnych uwarunkowań gospodarczych $\mathrm{z}$ chwilą utraty rentowności wiele filii popada w trudności. Wpływowi, większościowi akcjonariusze macierzystego zakładu w imię doraźnych celów decydują się poświęcić jedną lub kilka gałęzi. Stanowi to łagodniejszą wersję delokalizacji.

Delokalizacja obejmuje kilka scenariuszy nabywania podmiotów gospodarczych i wyznacza następujące strategie:

- wykupienie przedsiębiorstwa lub jego części,

- tworzenie ex nihilo nowej siedziby zagranica,

- holdingi z dokonaniem fuzji istniejących filii zakładów,

- tworzenie joint-ventures.

Bezpośrednie inwestycje zagraniczne stają się nadzieją dla biedniejszych społeczeństw. Gdy aktywność już istniała, wzbogacają rodzimy kapitał, pozwalają zachować specjalizacje i niekoniecznie likwidują aktywność miejscową. Inwestor wtapia się w kraj, omijając tym samym zawyżające ceny produktów zapory celne, akcyzy, certyfikaty. Produkcja zdelokalizowana poza krajem zapewnia zatrudnienie $\mathrm{w}$ procesie konwergencji i skraca dystans cywilizacyjny. Współczesna telekomunikacja ułatwia pokonanie barier stworzonych przez rozproszenie miejsc pracy. Przyciaga nowe technologie, nawet uprzednio chronione, pozwala przetworzyć surowce miejscowe. Delokalizacja daje szansę rozwoju kraju niedoinwestowanego, o potulniejszej i tańszej sile roboczej, mniejszych wymaganiach co do bezpieczeństwa pracy.

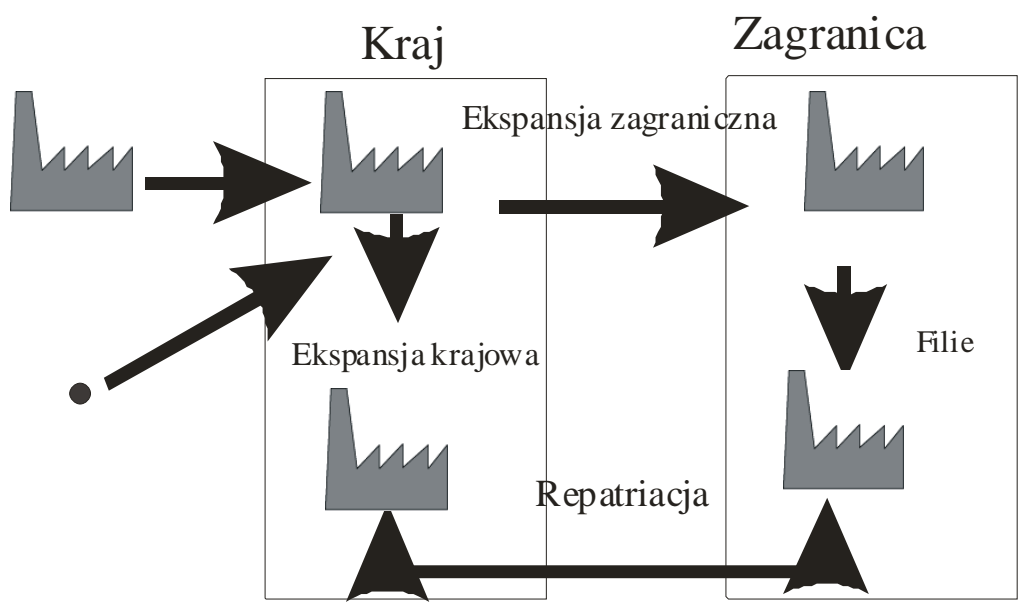

Ryc. 1. Delokalizacja przedsiębiorstw 
Coraz więcej państw otwiera się na świat, dzięki temu globalny rynek pracy rozszerza się na kraje środkowo-wschodniej Europy. Te, w większości kraje kandydackie, są dogodnie usytuowane na peryferiach Unii. W związku z powyższym, korzystają z dynamiki regionalnej, krótszego okresu dostarczania produktów. Daje to szanse na wytwarzanie dóbr, których wyłączność miały dotychczas kraje wysoko uprzemysłowione, a przede wszystkim pozwala przeorientować firmy na eksport. Dobra wytwarzane w przedsiębiorstwach zdelokalizowanych są zazwyczaj eksportowane do „drogich krajów”.

Tabela 1. Kumulowane wartości biz w Polsce.

Uporząadkowanie krajów według wielkości wkładu. Stan na czerwiec 2003

\begin{tabular}{|c|c|c|c|c|}
\hline Pozycja & Kraj & $\begin{array}{c}\text { Zainwestowany kapital } \\
\text { (w milionach USD) }\end{array}$ & $\begin{array}{l}\text { Zaplanowane } \\
\text { inwestycje }\end{array}$ & $\begin{array}{c}\text { Liczba } \\
\text { zakładów }\end{array}$ \\
\hline 1 & Francja & $12,528.8$ & $2,153.6$ & 92 \\
\hline 2 & Holandia & $8,906.4$ & 780.3 & 106 \\
\hline 3 & USA & $8,285.6$ & $2,541.6$ & 124 \\
\hline 4 & Niemcy & $7,952.5$ & $1,598.6$ & 227 \\
\hline 5 & Włochy & $3,711.3$ & $1,146.7$ & 65 \\
\hline 6 & Wielka Brytania & $3,542.5$ & 279.8 & 45 \\
\hline 7 & Szwecja & $3,033.2$ & 288.4 & 58 \\
\hline 8 & Międzynarodowe & $2,176.0$ & 737.0 & 16 \\
\hline 9 & Dania & $1,903.6$ & 301.6 & 43 \\
\hline 10 & Belgia & $1,901.5$ & 398.9 & 25 \\
\hline 11 & Korea Płd. & $1,471.8$ & 5.0 & 4 \\
\hline 12 & Rosja & $1,291.9$ & 350.0 & 3 \\
\hline 13 & Irlandia & $1,081.6$ & 68.2 & 3 \\
\hline 14 & Szwajcaria & $1,053.8$ & 166.9 & 22 \\
\hline 15 & Austria & $1,047.5$ & 183.6 & 38 \\
\hline 16 & Cypr & 998.9 & 185.0 & 3 \\
\hline 17 & Grecja & 556.5 & 0 & 3 \\
\hline 18 & Portugalia & 554.4 & 66.6 & 4 \\
\hline 19 & Finlandia & 437.9 & 177.6 & 19 \\
\hline 20 & Hiszpania & 387.1 & 38.5 & 11 \\
\hline 21 & Japonia & 314.5 & 237.3 & 12 \\
\hline 22 & Norwegia & 290.7 & 67.4 & 13 \\
\hline 23 & Kanada & 211.7 & 284.4 & 14 \\
\hline 24 & Chorwacja & 173.0 & 16.0 & 2 \\
\hline 25 & Luksemburg & 108.6 & 15.2 & 12 \\
\hline 26 & Turcja & 100.1 & 58.0 & 4 \\
\hline 27 & Izrael & 70.4 & 131.0 & 4 \\
\hline 28 & Słowenia & 66.2 & 42.5 & 2 \\
\hline 29 & Czechy & 62.7 & 0 & 4 \\
\hline 30 & RSA & 57.2 & 0 & 1 \\
\hline 31 & Węgry & 48.5 & 17.2 & 4 \\
\hline 32 & Chiny & 45.0 & 45.0 & 2 \\
\hline 33 & Filipiny & 40.0 & 0 & 1 \\
\hline 34 & Australia & 28.5 & 1.0 & 2 \\
\hline 35 & Lichtenstein & 14.4 & 17.0 & 4 \\
\hline 36 & Tajwan & 5.7 & 200.0 & 1 \\
\hline \multicolumn{2}{|c|}{ Inwestycje > 1 mln USD } & $64,460.30$ & $12,599.80$ & 993 \\
\hline \multicolumn{2}{|l|}{ Ogółem } & $68,301.50$ & & \\
\hline
\end{tabular}

Źródło: PAIiIZ (Państwowa Agencja Informacji i Inwestycji Zagranicznych) 
Tabela 1 upewnia nas, że nasz kraj choć niezbyt atrakcyjny pod względem napływu biz (bezpośrednich inwestycji zagranicznych), postrzegany jest na arenie europejskiej jako względnie stabilny. Około tysiąca zaangażowanych zakładów z całego świata zainwestowało tu ponad milion dolarów. W tej liczbie 13 zakładów z byłego bloku wschodniego. Były monopol państw w Europie Środkowo-Wschodniej zamieniony został na monopol obcego kapitału. Transformacja ustrojowa pociągnęła za sobą swobodę decydowania o swoim losie, doborze partnerów eksportowych, ale generowała bezrobocie i demontaż praw socjalnych. Nastąiła nieuchronna fragmentaryzacja procesu produkcji. Wraz z nią, w zależności od zapotrzebowania regionalnego, delokalizacja. Kraje sąsiednie, jak Ukraina czy Białoruś, oferują koszta pracy niższe niż w Polsce. Dla porównania, obciążenia patronackie pod koniec ubiegłego wieku wynosiły odpowiednio: Czechy 35\%, Słowacja 38\%, Węgry 40\%, Polska $47 \%$. Średnie miesięczne wynagrodzenie również mocno odbiega od polskich stawek. Stawia to Polskę w gorszej sytuacji przetargowej.

Tabela 2. Główne charakterystyki krajów kandydackich

\begin{tabular}{|l|c|c|c|c|c|}
\hline & WKB euro & Rok 2002 & \\
& mieszkańca & $\begin{array}{c}\text { Średnia } \\
\text { pensja }\end{array}$ & $\begin{array}{c}\text { Stopa } \\
\text { bezrobociąna } \\
\text { brutto }\end{array}$ & $\begin{array}{c}\text { Kumulowane } \\
\text { biz \$ }\end{array}$ & \% PKB \\
\hline Bułgaria & 6230 & 139 & 17,8 & 547 & $\begin{array}{c}\text { sektora } \\
\text { prywatnego }\end{array}$ \\
\hline Czechy & 14750 & 510 & 7,3 & 3413 & 18,2 \\
\hline Estonia & 10030 & $328 *$ & 10,3 & 1864 & 80 \\
\hline Litwa & 9850 & $308^{*}$ & 13,6 & 1024 & 70 \\
\hline Lotwa & 8700 & $280 *$ & 12,3 & 1336 & 65 \\
\hline Polska & 10230 & 553 & 19,9 & 997 & 80 \\
\hline Rumunia & 6000 & 174 & 8,5 & 405 & 44,5 \\
\hline Slowenia & 18070 & 1041 & 6,4 & 1722 & 65 \\
\hline Słowacja & 11890 & 336 & 18,5 & 1784 & 80 \\
\hline Węgry & 13720 & 504 & 5,8 & 2253 & 80 \\
\hline
\end{tabular}

* z braku danych dla 2002, dla 2001

Źródło: Eurostat

Przeciwdziałając niepożądanym skutkom, Polska stara się koncentrować na wysokiej jakości swoich produktów i usług i stosuje agresywniejszą ekspansję. Wymaga to znacznego zwiększenia nakładów na kształcenie, szkolenia pracowników. Przemysł, zwłaszcza jego sektor prywatny, aspirować powinien do sprostania unijnej konkurencji. Bezpośrednią i najszybszą metodą jest przejęcie przy renomowanych produktach strategii marketingowej made in Poland powszechnie stosowanej i podnoszącej prestiż. Mechanizmy delokalizacyjne wprowadzają gospodarkę $\mathrm{w}$ intensywny strumień wymiany ponadnarodowej, w konieczną nieraz radykalną restrukturyzację branż. Koszta takiego przedsięwzięcia są wysokie. Ekonomiczne terytorium narodowe jest składową poszerzonej przestrzeni unijnej, ale nadrzędny pozostaje interes narodowy. 


\section{MOTYWY DELOKALIZACJI}

Minimalny koszt wytwarzania nie jest jedynym czynnikiem skłaniającym do delokalizacji. Nadrzędnym celem jest zawsze zysk. Potencjalny rozwój zakładów, obecność na rynkach zagranicznych są głównymi przyczynami przemieszczeń. W wyborze nowej lokalizacji kluczową rolę gra dostępność przestrzenna, koszt pokonania przestrzeni, obciążenia pracodawcy, wysokość VAT, stabilność cen, mniejsze wymagania w dziedzinie bezpieczeństwa i higieny pracy, wsparcie instytucjonalne, zadowalająca infrastruktura, sprzyjający klimat społeczny, kultura przemysłowa oraz motywacja do pracy lokalnej załogi. Duże znaczenie mają także zdobycze socjalne wywalczone na danym terytorium: wiek przejścia na emeryturę, zapewniony wzrost płac, czas pracy, długość urlopów. Zasadniczymi czynnikami są dostęp do obfitych, tanich, nieskażonych i niezmodyfikowanych genetycznie półproduktów, które redukują koszty transportu i opłaty celne.

Kary za przekroczenie norm zanieczyszczanie środowiska mogą skłonić firmy do delokalizacji do miejsc mniej restrykcyjnie dbających o ochronę środowiska, oczywiście w ten sposób jakość powietrza na świecie nie ulegnie poprawie.

Klęski żywiołowe mogą zniweczyć poczynione wysiłki: pożar, ponawiające się powodzie, nadmierne skażenie środowiska przyrodniczego, zagrożenia terrorystyczne, względy bezpieczeństwa również mogą wpływać na podjętą decyzję. Bogatsze kraje chętnie przenoszą „brudne” zakłady poza swoje granice. Redukują i wywożą odpady radioaktywne, chemiczne poza własne terytorium. Utylizacja odpadów jest kosztowna i nieobojętna dla otoczenia. Niszczenie środowiska odbywa się na zasadzie pozbywania się brudnych technologii, na oddaleniu produkcji do regionów świata o niższych standardach i wymaganiach ekologicznych.

„Przyjacielskie” giełdowe przejęcie przedsiębiorstwa z zachowaniem całej lub części załogi zmierza do kontynuowania produkcji ewentualnie zmiany asortymentu. „Nieprzyjacielskie" może się zakończyć wykupem zakładu z wygaszeniem produkcji, wypompowaniem środków dla ratowania własnego przedsiębiorstwa, co okazuje się najbardziej niekorzystnym rozwiązaniem.

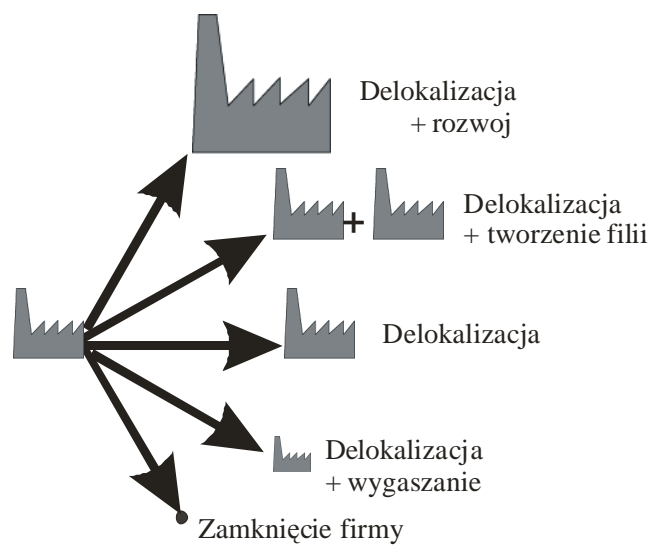

Ryc. 2. Strategie rozwoju firm zdelokalizowanych 
Przedsiębiorstwa, które się przenoszą, prowokują lokalne dramaty. Konsekwencją są wycieki powiązanych licznych inwestycji, które pozbawiają źródeł zarobkowania ludność uboższych obszarów rolniczych.

\section{Gdzie się delokalizuje?}

Kraje Europy Środkowo-Wschodniej położone na peryferiach Unii Europejskiej są celem licznych delokalizacji. Każdy z nich zabiega o przyciagnięcie przedsiębiorstw zagranicznych, prześcigają się w ofertach politycznych, przemysłowych, handlowych, mnożą ulgi, strefy bezcłowe i uznane za nielojalną konkurencję Specjalne Strefy Ekonomiczne.

Siła przyciagająca „Europy bogatych” jest czynnikiem, który wymusza wprowadzenie reform. Z drugiej strony, kroki podejmowane przez przedsiębiorstwa wielonarodowe przy organizowaniu działalności poza strukturami krajowymi mogą prowadzić do nadużywania potęgi gospodarczej, do uniemożliwienia kontrolowania procesu produkcji daleko od firmy macierzystej.

W zbiorze licznych przemieszczeń rozróżniamy delokalizację lokalną, regionalną, wewnątrzkrajową, działającą z opóźnieniem, od bardziej trwałych delokalizacji pozakrajowych. Kolejne pierścienie oddalające się od zakładu przeniesionego obejmują obszary coraz bardziej jednorodne.

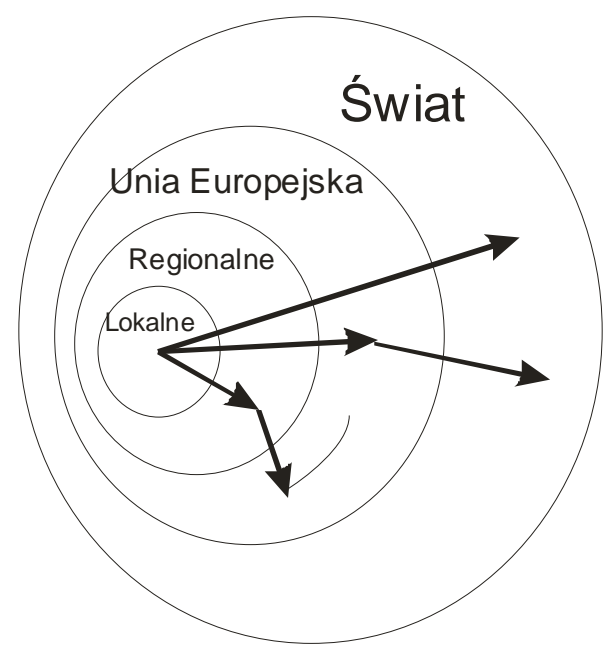

Ryc. 3. Koncentryczne otoczenia zakładu delokalizowanego: lokalne $\subset$ regionalne $\subset$ krajowe $\subset$ kontynenta Ine $\subset$ światowe

Z chwilą pogorszenia warunków produkcji w wybranym czasowo miejscu, dość szybko dojść może do relokalizacji, do sprowadzenia na powrót zakładu produkcyjnego. Przeniesienie siedziby umiejscowionej $\mathrm{w}_{\mathrm{o}}$ do $\mathrm{P}_{\mathrm{j}}$, to ocena podjętego ryzyka, które usprawiedliwia taki transfer. W przeanalizowaniu potencjalnych środowisk przemysłowych chodzi o:

- rozpoznanie zasobów siły roboczej i ich gustów,

- przeanalizowanie sieci i zdolności aprowizacyjnych,

- sporządzenie montażu finansowego i prawnego operacji,

- zaplanowanie rozruchu produkcji. 


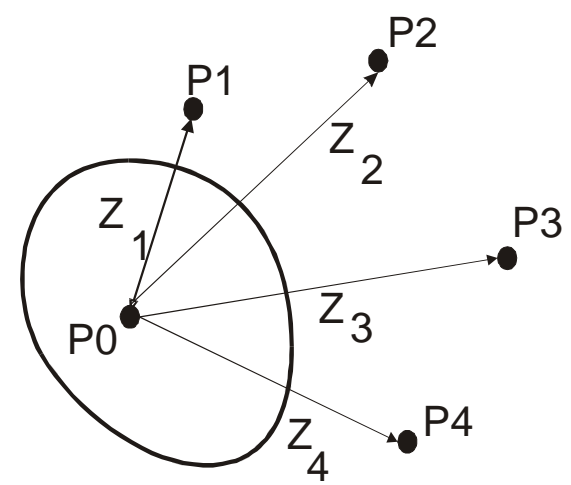

Ryc. 4. Wyznaczanie najkorzystniejszej delokalizacji w zbiorze potencjalnych miejscowości

Wybór lokalizacji przedsiębiorstwa wyznacza maksymalna wartość zysków dla każdej zmiennej $\mathrm{X}_{\mathrm{i}}$, Pracodawca korzysta $\mathrm{z}$ kryterium $\mathrm{Z}_{\mathrm{i}}=\left|\mathrm{X}_{0}-\mathrm{X}_{\mathrm{i}}\right|$, gdzie $\mathrm{X}_{\mathrm{o}}$, to warunki panujące w miejscu $\mathrm{P}_{\mathrm{o}}$. Dla analiz komparatywnych poszczególne zyski wyrażone są w wybranej walucie. Uprzednio, należy doprowadzić do utworzenia zgodnej macierzy cech, w której wszystkie współczynniki korelacji mają ten sam znak.

$$
Z_{i}=\left\{\begin{array}{ccc}
>0 & \Rightarrow & \text { korzystniejsza lokalizacja } \\
=0 & \Rightarrow & \text { sytuacja ekwiwalentna } \\
<0 & \Rightarrow & \text { gorsza lokalizacja }
\end{array}\right.
$$

Dla każdej upatrzonej lokalizacji $\mathrm{P}_{\mathrm{i}}$ otrzymujemy dodatnią sumę przyrostów:

$$
Z=\sum_{i=1}^{k}\left(Z_{1}+Z_{2}+\ldots+Z_{k}\right) .
$$

Strategia przemieszczenia polega na malejącym uporządkowaniu kryteriów:

$Z_{I} \geq Z_{I I} \geq \ldots \geq Z_{k}$ i wytypowaniu hyper-wzrostu: $\min _{I \leq i \leq K}\left\{Z_{\mathrm{i}}\right\}$.

Oczywiście, względy pozaekonomiczne mogą również zdecydować o innej lokalizacji. Każda z komponent $Z_{\mathrm{i}}$, ułożona według ustalonej hierarchii, winna wnosić maksymalny zysk. Dopuszcza się dla niektórych komponentów lekkie straty, byleby bilans wypadł dodatnio, aby delokalizacja stała się opłacalna. Wysokie wartości pewnych składowych sumy wyznaczają zmienne, na których w danym miejscu można najwięcej zyskać. Liczba zakładów do dyspozycji jest magnesem przyciagającym koncerny. Czas przeprowadzki winien być jak najkrótszy. Wydłużenie go zmniejsza wpływy. Zastój generuje straty. O nim decyduje klimat społeczny, biurokracja, ewentualny zaplanowany wkład korupcyjny. Wyrównanie zespołu warunków doprowadzi do nieopłacalności delokalizacji, co pociaga za sobą zamarcie prób przeprowadzek. $Z$ upływem czasu, gdy sytuacja w nowym miejscu się polepsza, staje się od nowa opłacalna delokalizacja. Z tych wszystkich wymienionych ruchów delokalizacyjnych wyłania się nowa mapa uprzemysłowienia. Kilkuletnie podręczniki z geografii przemysłu przechodzą do lamusa. 


\section{Społeczne protesty}

Próby delokalizacji mobilizują opinię publiczną oraz konsolidują skłócone związki pracownicze do walki o zachowanie miejsc pracy. O stopniowym lub całkowitym zamknięciu zakładów względnie o delokalizacji i jej skutkach głoszą media. Groźba przeniesienia produkcji zwiększa bezrobocie, zwłaszcza wśród pracowników o niższych kwalifikacjach. Zwalniani pracownicy w przytłaczającej większość pozostaną bez szans na szybkie zatrudnienie. Wymuszane migracje zarobkowe doprowadzają do obumierania opuszczonych miast. W zamian rozkwitają te miejscowości, którym udało się przechwycić zakłady.

Delokalizacja, zazwyczaj nieodwracalna, jest często nadużywana. Przedsiębiorstwa opuszczające kraj wpływają paraliżująco na sprawność decyzyjną zarządów. Chodzi o rozróżnienie strategii w celu ekspansji i zdobywania rynków od skrywanej chęci korzystania ze sprzyjających warunków socjalnych i fiskalnych. Pewne firmy wykorzystują fundusze restrukturyzacyjne i dostępne ulgi podatkowe, zanim zamkną działalność po okresie ochronnym. Takie działania oszukańcze bywają nieraz sankcjonowane.

Problemy moralne, jakie pojawiają się przy tej okazji, są przedmiotem etyki biznesu. Chodzi o moralną odpowiedzialność, jaką przedsiębiorcy-renegaci ponoszą wobec wspólnoty politycznej, dostawców, kooperantów, zawiedzionych wspólnot lokalnych i regionalnych. Uspakaja się ludność, że operacje delokalizacji są neutralne, jako że stanowiska pracy są łatwo przechwytywane przez małe i średnie przedsiębiorstwa. Zazwyczaj zwolnionym ludziom proponuje się gorsze warunki pracy i niższe wynagrodzenia. Przenoszenie zakładów to tragedia dla pracowników i ich rodzin. Dochodzi do demontażu i wywozu urządzeń w czasie nieobecności załogi. Organizowane są wtedy manifestacje w obronie zakładu, eskalują się formy protestów, od pikiet, blokad, strajków okupacyjnych, poprzez przetrzymywanie członków dyrekcji, niszczenie produkowanych towarów, do podpalania zakładów włącznie. Zdarza się, że zagraniczne koncerny rezygnują z kupna upatrzonych spółek, gdy dowiadują się o skali wpływów związków zawodowych.

\section{Konsekwencje społeczne}

Z. Bauman zauważył, że: „W zglobalizowanym świecie lokalność jest oznaką społecznego upośledzenia i degradacji”. Gwarantowana jest wolność osadzania się w dowolnym miejscu. Jednakże ponadnarodowe korporacje, bezwzględnie forsujące interesy firmy, narzucają swoje struktury. Przemyślnie zaplanowane akcje, poparte zagmatwanymi obwarowaniami prawnymi, wymykają się narodowej kontroli. Dla kraju przejmującego działalność ma to aspekty pozytywne: zmniejsza bezrobocie, stymuluje rozwój gospodarczy, dynamizuje region. Decyzja osadzenia spółek wymaga często wsparcia finansowego w postaci bezpośrednich inwestycji zagranicznych. Odgrywają one decydującą rolę w zaopatrywaniu produktów i usług, w jego integracji z siedzibą macierzystą. Biz polepszają rynek poprzez wzmocnienie zakładów rodzimych i bezpośredni kontakt $\mathrm{z}$ handlem i produkcją międzynarodową. Inwestycje te to dla krajów-odbiorców czysta korzyść. Na ogół oczekują po nich napływu nowoczesnych technologii, nagromadzonego doświadczenia oraz odpowiedniego finansowania, oddłużenia, wzrostu zdolności eksportowych.

Tymczasem inwestorzy mogą kierować się też inną logiką, mogą dążyć do uzyskania udziału w kapitale istniejącego przedsiębiorstwa po to, aby zapewnić sobie kontrolę nad konkurentem czy uzyskać dostęp do taniej i słabo chronionej przez związki zawodowe siły 
roboczej. Mogą też szukać okazji do upłynnienia zatruwających środowisko już zakazanych lub przestarzałych technologii.

$\mathrm{Z}$ rozwojem środków transportu kurczy się przestrzeń. Dla przykładu, wielu Francuzów przenosi siedziby przedsiębiorstw do Londynu, gdzie podatki są niższe, biurokracja mniej doskwiera, a dogodny dojazd szybką koleją pod Kanałem La Manche ułatwia rozwój firmy.

\section{Przemysł spożywczy i jego ekspansja}

Dla przykładu proponujemy prześledzenie losów prężnego przemysłu rolno-spożywczego i zakładów tej branży. Agrobiznes, przy nadmiarze słabo opłacanej i niezbyt wykwalifikowanej siły roboczej, jest rentownym filarem gospodarki polskiej. Zatrudnia ponad $4 \%$ populacji w wieku produkcyjnym. Na terenie kraju działa około 27000 małych i średnich przedsiębiorstw, w tym 350 dużych zakładów. Inwestycje w przemyśle spożywczym składają się w przeważającej części z dużych europejskich korporacji transnarodowych. W skład tego imperium przemysłowego wchodzi wiele przedsiębiorstw rozmieszczonych na wszystkich kontynentach, w których zatrudnionych są miliony osób.

W Polsce dotychczas osiedliły się i niepodzielnie panują spółki z obcym kapitałem. W pejzaż wpisały się szyldy niekwestionowanych światowych liderów: Agros, Alima-Gerber, Bakoma, Beguin-Say, Bestfoods, Bondouelle, Carlsberg, Coca Cola, Danone, Kama Foods, Kellog's, Kraft Jacobs Suchard, Lisner, Master Foods, Nestlé, PepsiCo, Shuldtad, Unilever. Firmy te solennie zobowiązały się do rozwijania produkcji i używania niemal wyłącznie komponentów krajowych. Zasoby zagraniczne wprowadzane na nasz rynek miały wzbogacać asortyment i zmieniać przyzwyczajenia konsumentów, do makdonaldyzacji włącznie.

Światowe koncerny podzieliły między siebie polski rynek cukierniczy przejmując smakowite znaki firmowe, jak: Aquavit, Bałtyk, Blikle, Goplana, Herbapol, Hortex, Lajkonik, Mieszko, Olza, Polmos, Pomorzanka, Śnieżka, Wawel, Winiary. Starają się wytwarzać i sprzedać produkty uznanych marek lokalnych po dostępnej cenie. Ich produkty zaopatrują około 2300 punktów sprzedaży, w tej liczbie liczne hipermarkety: Géant, Jumbo, Auchan, Leclerc, Selgros, Carrefour, Tesco. Rozczarowani stratami bądź słabymi wpływami firmy ograniczają zatrudnienie w polskich zakładach i przenoszą produkcję za granicę. Pewne lokalne władze zdołały po odpowiednich ustępstwach zatrzymać pracodawców, jak np. zakłady Bahlsena w Oławie czy fabrykę frytek w Słupsku. Inne, jak np. koncern Nestlé-Polska wyprowadza produkcję z zakładów w Poznaniu, Lesznie i Kargowej. Poznańska Goplana, zgodnie z założeniami, ma w przeciągu roku wygasić produkcję i przenieść do Pecs na Węgry. Inwestycje przyczyniły się również do umocnienia własnych marek. Obecnie są produkowane w Czechach, Bułgarii, Rosji i na Węgrzech. Dają tam miejsca pracy kosztem miejsc w Polsce. Co więcej produkowane są tam znakiem Goplany i jako hity eksportowe trafiają na polski rynek. Plony rolne są łatwiej zbywalne. Gorzej z wyrobami spożywczymi. Obok dostosowania się do obowiązujących unijnych norm sanitarnych, najwięksszym wyzwaniem jest uzyskanie certyfikatów ISO. Bez niego nie sprostają konkurencji międzynarodowych koncernów, np. mleczarnia w Słupsku, będąca własnością Nestlé, odmówiła odbioru mleka od ok. 100 dostawców.

Należy wierzyć, że integracja wewnątrzeuropejska może złagodzić negatywne efekty delokalizacji i pomóc w zyskaniu przez Polskę właściwej pozycji w gospodarce europejskiej. 


\section{Literatura}

Samdry C., 2002, Inwestycje zagraniczne w Europie Wschodniej. Strona: http://www.czerwonysalon.republika.pl/

Michalet C-A. 2003, Les delocalisations, une chance pour renforcer la competitivite de l'Union Europeenne. Rencontres economiques d'Aix-en-Provence

Trójstronna deklaracja zasad dotyczqcych przedsiębiorstw wielonarodowościowych i polityki spotecznej. Międzynarodowe Biuro Pracy Genewa. Listopad 2000 